Available online at GSC Online Press Directory

GSC Biological and Pharmaceutical Sciences

e-ISSN: 2581-3250, CODEN (USA): GBPSC2

(RESEARCH ARTICLE)

\title{
Chemical composition, antimicrobial and free- radical scavenging activity of essential oils from Khaya senegalensis (Desr) A. Juss
}

\author{
Opawale Benjamin Oyewale* and Adaramola-Ajibola Modupe Khadijat \\ Department of Science Laboratory Technology, Rufus Giwa Polytechnic, Owo, Nigeria.
}

Publication history: Received on 21 November 2019; revised on 29 November 2019; accepted on 03 December 2019

Article DOI: https://doi.org/10.30574/gscbps.2019.9.3.0220

\begin{abstract}
Investigations were conducted to evaluate the chemical composition, free-radical scavenging activity and the antimicrobial efficacy of essential oils obtained from the leaf and stem bark of Khaya senegalensis (Desr) A. Juss. The plant materials (leaf and stem bark) were dried under shade, blended and sieved to obtain their respective powders. The essential oils obtained by subjecting the powders to hydro distillation method for 3hr in a Clevenger type apparatus were then investigated using standard methods. The average percentage yields of the oils were $0.85 \pm 0.01 \%$ ) and $0.50 \pm$ $0.00 \%$ for the leaf and stem bark respectively. The major constituents of the essential oils were khayasinine (39.11\%), 7-diacetyl-7oxogedunine (27.09\%) and methyl- angolensate (11.51\%) for the leaf oil and ivorenolide (28.77\%), khivorine (16.33) and 3-diacetyl khivorine (16.10\%) for the stem oil. The inhibitory concentration (IC 50 ) of the free radical scavenging activity of the oils were $1.40 \pm 0.29$ and $1.00 \pm 0.02$ for the leaf and stem oils respectively. The mean diameter of the zones of inhibition exhibited by the oils at $50 \mu \mathrm{g} / \mathrm{ml}$ was between $7.67 \pm 0.67 \mathrm{~mm}$ and $16.33 \pm 0.33 \mathrm{~mm}$ while the MIC was between $5 \mu \mathrm{g} / \mathrm{ml}$ and $40 \mu \mathrm{g} / \mathrm{ml}$ for the plant materials. The plant oils remarkably inhibited the growth of Bacillus subtilis ATCC6633, Candida albicans ATCC10231, Escherichia coli, Klebsiella pneumoniae and Staphylococcus aureus. The activity of the plant oils compared favourably with the antibiotics used as positive control. The demonstration of significant antimicrobial and high free radical scavenging activities in addition to the presence of bioactive compounds in the plant materials could explain the basis for the use of K. senegalensis in the traditional treatment of diseases caused by the test microorganisms.
\end{abstract}

Keywords: Chemical composition; Antimicrobial; Antioxidant; K. senegalensis

\section{Introduction}

Medicinal plants are rich in secondary metabolites which are potential sources of drugs of therapeutic importance. The world Health Organisation (WHO) estimates that a considerable number of people in Sub-Saharan African rely on traditional complementary and alternative medicine to meet their primary health needs [1]. The emergence and spread of antibiotic resistance, as well as the evolution of new strains of diseases entails the development of some potential source of novel drugs [2]. The evaluation of various plants according to their traditional uses and medical value based on their therapeutic efficacy leads to the discovery of newer and recent drugs for treating various ailments [3, 4]. Pharmaceutical studies have also accepted the value of essential oils from medicinal plants as potential source of bioactive compounds in antimicrobial discovery. The essential oils obtained from them have been traditionally used for the treatment of infections and diseases all over the world $[5,6]$.

Khaya senegalensis (Desr) A. Juss commonly known as Dry Zone Mahogany is a species of plant in the Meliaceous family found in many African countries. It is a savanna tree, easily recognized by its round evergreen crown of dark, shining foliage pinnacle leaves and characteristics round capsules. A tree of $30 \mathrm{~m}$ high and $3 \mathrm{~m}$ girth with dense crown and short

\footnotetext{
${ }^{*}$ Corresponding author

E-mail address: benjaminopawale@gmail.com
} 
bole covered with dark grey scaly bark. The leaves are with 3-4 pairs of leaflets, $5-10 \mathrm{~cm}$ long by $2.5-5 \mathrm{~cm}$ broad, more or less elliptic, round; obtuse or shortly acuminate at apex with stalks of leaflets of about $4 \mathrm{~mm}$ long [7]. The bark extract is used for treating jaundice, dermatoses, hookworm infection and malaria [8]. Considering the vast potential of plants as sources of antimicrobial drugs, this research work was designed to investigate the chemical composition, antimicrobial and free- radical scavenging activity of essential oils from Khaya senegalensis in order to validate its folkloric use.

\section{Material and methods}

\subsection{Collection and processing of plant materials}

Fresh leaves and stem barks of Khaya senegalensis (Desr) A Juss were harvested from uncultivated farmlands located in Owo, Ondo State, Nigeria between October 2017 and May 2019. The plant materials were collected in clean plastic bags while the plants were still moist with the morning dew and properly labeled. The plants were then authenticated at the Herbarium of the Department of Botany, University of Lagos. Voucher specimens were deposited at the Department of Forestry and Wood Technology, Rufus Giwa Polytechnic, Owo. The authenticated plants were washed and cleaned thoroughly with tap water and then air-dried under shade for six weeks. The dried samples were then ground into coarse powder, stored in clean air- tight containers and kept in a cool, dry place until required for use.

\subsection{Extraction of essential oils}

Essential oils were separately extracted from the leaf and stem bark of the plant by steam distillation. A five hundred grams portion of the respective plant parts in $2000 \mathrm{ml}$ of distilled water was hydro distilled using an improvised Stovestill apparatus for $5 \mathrm{hr}$ to obtain the oil. The steam distillate was dried over anhydrous sodium sulphate and $10 \mathrm{mg}$ of it was diluted with $100 \mathrm{ml}$ of $0.01 \%$ Tween-20 to obtain a $100 \mu \mathrm{g} / \mathrm{ml}$ solution. Serial dilution of each $100 \mathrm{ml}$ stock solution was made with $0.01 \%$ Tween-20 to give test solutions $50,25,12.5$ and $6.3 \mu \mathrm{g} / \mathrm{ml}$ respectively [9].

\subsection{Collections of test microorganisms}

Fifteen clinical isolates (Bacillus subtilis, Escherichia coli, Enterococcus faecalis, Klebsiella pneumonia, Pseudomonas aeruginosa, Salmonella typhi, Staphylococcus aureus, Staphylococcus epidermidis, Streptococcus spp, Streptococcus pyogenes, Aspergillus flavus, Candida albicans, Candida glabrata, Cryptococcus neoformans and Trichophyton rubrum) and five typed cultures ( Bacillus substilis ATCC 6633, Stapylococcus aureus ATCC 25923, Escherichia coli ATCC 25922, Salmonella typhi ATCC 6539 and Candida albicans ATCC 10231) obtained from Federal Medical Center, Owo and Federal Institute of Industrial Research, Oshodi, Lagos State respectively were used for this study.

\subsection{Purification of test organisms}

The organisms were confirmed by sub-culturing into Muller Hinton broth and Sabouraud Dextrose broth and incubated at $37^{\circ} \mathrm{C}$ for $18 \mathrm{hr}$ (for bacteria) and $25^{\circ} \mathrm{C}$ (for fungi). They were further streaked on Muller Hinton agar and Sabouraud Dextrose agar and incubated at $37^{\circ} \mathrm{C}$ for $18 \mathrm{hr}$ and $25{ }^{\circ} \mathrm{C}$ for 5 days for bacteria and fungi respectively. Biochemical tests were used to confirm the bacterial species and kept on agar slant at refrigeration temperature until needed [10].

\subsection{Standardization of microbial culture}

A loopful of bacterium test organism was aseptically inoculated into Mueller Hinton broth (MHB) and incubated for 24 $\mathrm{h}$ at $37^{\circ} \mathrm{C}$. A portion of $0.2 \mathrm{ml}$ from the $24 \mathrm{~h}$ culture of the organism was dispensed into $20 \mathrm{ml}$ sterile Muller Hinton broth and incubated for $3-5 \mathrm{~h}$ to standardize the culture to $0.5 \mathrm{McFarland}$ standards $\left(1.0 \mathrm{x} 10^{6} \mathrm{cfu} / \mathrm{ml}\right)$. Molds inoculum suspensions were obtained by fine colonies (>1mm diameter) from $24 \mathrm{~h}$-old cultures grown on Saboraud dextrose agar and lawn prepared were suspended in $5 \mathrm{ml}$ of sterile saline $(0.85 \% \mathrm{NaCl})$. The inoculum suspensions were shaken for $15 \mathrm{~s}$ and the inoculum density was adjusted to the turbidity of a $0.5 \mathrm{McFarland}$ Standard (equivalent to $1 \times 10^{6} \mathrm{sfu} / \mathrm{ml}$ ) with sterile saline according to the method of [11].

\subsection{In vitro antibacterial susceptibility test}

The essential oils obtained from the test plant materials were screened against the test bacteria by agar well diffusion method [12]. A 25ml aliquot of Mueller Hinton agar (MHA, Lab Oratorios Britania, Argentina) was poured into each Petri plate. When the agar solidified, the pathogenic test organisms were inoculated on the surface of the plates $\left(1 \times 10^{6}\right.$ $c f u / \mathrm{ml}$ ) using a sterile glass spreader and allowed to sink properly. Subsequently, the surface of the agar was punched with $6 \mathrm{~mm}$ diameter cork borer into wells and a portion of $50 \mu \mathrm{l}$ of each of the oil concentrations was filled into the wells. Control wells containing the same volume of $30 \%$ dimethyl sulphoside (DMSO) served as negative control, while 
Opawale and Adaramola-Ajibola / GSC Biological and Pharmaceutical Sciences 2019, 09(03), 026-034

Chloramphenicol $(50 \mu \mathrm{g})$ was used as positive control for the plates respectively and the plates were incubated at $37^{\circ} \mathrm{C}$ for $24 \mathrm{~h}$. Each experiment was carried out in triplicate and the diameter of the zones of inhibition was then measured in millimeters.

\subsection{In vitro antifungal susceptibility test}

A modified method of [12] was adopted. The essential oils obtained from the test plants were screened against test fungi by agar diffusion plate method using Saboraud Dextrose agar (SDA). An aliquot of $100 \mu$ of the respective spore suspension $\left(2 \times 10^{6} \mathrm{sfu} / \mathrm{ml}\right)$ was incorporated into the $25 \mathrm{ml}$ SDA medium and poured into sterile Petri-dish. This was allowed to set and punched with $6 \mathrm{~mm}$ cork borer. A portion of $50 \mu \mathrm{l}$ of each of the oil concentrations was introduced into the wells. Control wells containing the same volume of $30 \%$ dimethyl sulphoxide (DMSO) served as negative control while Miconazole

$(50 \mu \mathrm{g})$ was used as positive control. The test was carried out in triplicates and incubated at $25^{\circ} \mathrm{C}$ for $72 \mathrm{~h}$. The zones of inhibition were then measured in millimeters.

\subsection{Minimum inhibitory concentration (MIC)}

The MIC of the plant essential oils was determined by double dilution broth methods of [13]. Twofold serial dilutions of the oils were prepared in Mueller Hilton broth and Saboraud broth for bacteria and fungi respectively to achieve a decreasing concentrations ranging from the least concentration that produced clear zone of inhibition $(10 \mathrm{mg} / \mathrm{ml}$ to $0.156 \mathrm{mg} / \mathrm{ml}$ ). All tubes with the controls were labeled accordingly. Each dilution was seeded with $1 \mathrm{ml}$ of standardized inoculums $\left(1.0 \times 106 \mathrm{cfu} / \mathrm{ml}\right.$ for bacteria and $1.0 \times 106 \mathrm{sfu} / \mathrm{ml}$ for fungi) incubated at $37{ }^{\circ} \mathrm{C}$ for $24 \mathrm{hr}$ and $25^{\circ} \mathrm{C}$ for 72 $\mathrm{hr}$ for bacteria and fungi respectively. A tube containing only seeded broth (i.e. without plant extract) was used as the positive control while the un-inoculated tube was used as negative control. The lowest concentration of each oil sample that showed a clear zone of inhibition was when compared with the controls was considered as the MIC.

\subsection{Determination of antioxidant activity of plant essential oils}

A $3 \mathrm{ml}$ portion of the oil concentrations $(0.00$ to $2.0 \mathrm{mg} / \mathrm{ml})$ was added to $1 \mathrm{ml}$ of $100 \mu \mathrm{M}$ methanol solution of DPPH. The mixture was shaken vigorously and incubated in the dark at room temperature for $30 \mathrm{~min}$. The absorbance at $517 \mathrm{~nm}$ was measured against the blank (methanol) and ascorbic acid as positive control using a Spectrophometer. The DPPH radical scavenging activity (\%) was determined by the following equation:

DPPH radical scavenging: Activity $(\%)=($ Ao - As $) /$ Ao $\times 100$ where Ao $=$ absorbance of DPPH without sample; As $=$ absorbance of mixture of sample and DPPH. The radical scavenging activity of the samples was expressed as IC 50 value which is the effective concentration at which DPPH radicals were scavenged by $50 \%$ [14].

\subsection{Gas chromatography/mass spectrometer (GC/MS) analysis}

The GC/MS was performed using an Agilent Technologies 6890N gas chromatography connected to a 5973 INERT selected mass spectrophotometer HP5MS following the method of [15]. The column dimensions are $30 \mathrm{~m} \mathrm{x} 0.25 \mathrm{~mm}$ (i.d) x $0.25 \mu \mathrm{m}$ (film thickness). The ionization source temperature was held at $350 \mathrm{C}$ for $9 \mathrm{mins}$, increased by $3{ }^{\circ} \mathrm{C} / \mathrm{min}$ to 150 ${ }^{\circ} \mathrm{C}$ and held for 10 mins, increased by $10{ }^{\circ} \mathrm{C} / \mathrm{min}$ to $250{ }^{\circ} \mathrm{C}$ and increased by $3{ }^{\circ} \mathrm{C} / \mathrm{min}$ to $270{ }^{\circ} \mathrm{C}$ and held for 10 mins. The flow rate of the helium carrier gas (99.99\% purity) was $0.5 \mathrm{ml} / \mathrm{min}$, and the ionization energy was $70 \mathrm{eV}$. The samples were injected in split less mode. The injection volume for each sample was $2 \mu \mathrm{l}(2 \mathrm{mg} / \mathrm{ml})$ in methylene chloride and the MS spectra were acquired in the scan mode. The percentage of each compound in the sample was calculated by dividing its peak area by the total peak area of the sample and multiplying by 100 . It was assumed that the detector (Flame ionization detector, Perkin Elmer) response was the same for all the compounds [16]. The oil components were then identified by comparison of their retention indices to C5 - C20 n-alkanes (Sigma -Aldrich) and comparison of their MS spectra with those of the US National Institute of Standards and Technology (NIST) library and reference data.

\subsection{Data analysis}

Data were presented as mean standard error (SE). Significance difference between different groups was tested using two-way analysis of variance (ANOVA) and treatment means were compared with Duncan's New Multiple Range Test (DNMRT) using SSPS window 7 version 17.0 software. The significance was determined at the level of $p<0.05$. 


\section{Results and discussion}

The percentage extraction yields of the essential oils obtained from the leaf and stem bark of K. senegalensis were $0.70 \pm 0.01 \%$ and $0.50 \pm 0.11 \%$ respectively. The results revealed that the leaf material contained a higher amount of essential oil. The choice of plant organs used is justified by the fact that the leaf and stem bark are the major sites of choice for biosynthesis and storage of secondary metabolites responsible for the biological properties of plants [17,18]. However, the yields were significantly low which may be attributed to the solubility and antioxidant capacities of the plant materials. This finding agrees with the investigations by [19] who worked on similar medicinal plants.

The results of the antimicrobial susceptibility test of the essential oils of the plant materials against some pathogenic microorganisms as presented in Tables 1and 2 indicated zones of inhibition ranging from 8.33 \pm 0.33 to $14.33 \pm 0.33$ and7.67 \pm 0.33 to $16.33 \pm 0.33$ for the leaf and stem back oils respectively. The stem bark oil showed the most significant activity against Escherichia coli (16.33 \pm 0.33 ) followed by the leaf oil against Candida albicans ATCC10231 (14.33 \pm 033 while $P$. aeruginosa recorded the least sensitivity of $7.67 \pm 0.33$ against the stem bark oil at $50 \mu \mathrm{g} / \mathrm{ml}$. It was also noted that the antimicrobial activities of the plant oils were concentrations dependent against the test pathogens. The potent activity of the plant oils might be due to the phytocompounds of various metabolites present in the essential oils as well as the pathogen strains. This observation was in agreement with the antimicrobial investigations carried out by [20, 21].

Table 1 Antimicrobial activity of essential oil of K. senegalensis (DESR) A. Juss leaf on selected pathogens

\begin{tabular}{|c|c|c|c|c|c|c|c|}
\hline \multirow{2}{*}{$\begin{array}{c}\text { Conc. }(\mu \mathrm{g} / \mathrm{ml}) / \\
\text { Organisms }\end{array}$} & \multicolumn{7}{|c|}{ Zones of inhibition (mm) } \\
\hline & 6.3 & 12.5 & 25 & 50 & DMSO (30\%) & Chl & Myz \\
\hline B. $S$ & NI & $4.33 \pm 0.33^{\mathrm{a}}$ & $9.67 \pm 0.67 \mathrm{~b}$ & $12.67 \pm 0.67 \mathrm{c}$ & NI & $11.00 \pm 0.00^{\mathrm{b}}$ & N.A \\
\hline B. S ATCC6633 & $\mathrm{NI}$ & $5.33 \pm 0.33^{\mathrm{a}}$ & $10.00 \pm 0.58^{b}$ & $13.33 \pm 0.33^{c}$ & NI & $13.33 \pm 0.33^{c}$ & N.A \\
\hline S. $A$ & $\mathrm{NI}$ & $3.33 \pm 0.33^{\mathrm{a}}$ & $7.33 \pm 0.33^{b}$ & $11.33 \pm 0.33^{c}$ & NI & $18.00 \pm 0.00^{d}$ & N.A \\
\hline S. A ATCC 25923 & NI & $4.33 \pm 0.33^{a}$ & $7.33 \pm 0.33^{b}$ & $12.67 \pm 0.67 \mathrm{c}$ & NI & $20.33 \pm 0.88^{d}$ & N.A \\
\hline E. $C$ & $\mathrm{NI}$ & $\mathrm{NI}$ & $6.33 \pm 0.33$ a & $9.33 \pm 0.88^{b}$ & NI & $14.33 \pm 0.00 \mathrm{c}$ & N.A \\
\hline E. C АTCC25922 & NI & $\mathrm{NI}$ & $7.33 \pm 0.33^{a}$ & $10.33 \pm 0.33^{b}$ & NI & $16.33 \pm 0.33^{c}$ & N.A \\
\hline K. $P$ & $2.33 \pm 0.33^{a}$ & $5.33 \pm 0.33^{b}$ & $8.33 \pm 0.33^{c}$ & $12.33 \pm 0.33^{d}$ & NI & $15.00 \pm 0.58 \mathrm{e}$ & N.A \\
\hline Ps. A & $\mathrm{NI}$ & $4.33 \pm 0.33^{\mathrm{a}}$ & $6.33 \pm 0.33^{b}$ & $8.33 \pm 0.33^{c}$ & NI & $12.67 \pm 0.00^{d}$ & N.A \\
\hline$F$ & NI & $5.33 \pm 0.33^{\mathrm{a}}$ & $7.33 \pm 0.33^{b}$ & $10.00 \pm 0.58^{c}$ & NI & N.A & $\begin{array}{l}12.00 \\
\pm 0.00^{c}\end{array}$ \\
\hline C. $A$ & $3.33 \pm 0.33^{\mathrm{a}}$ & $6.00 \pm 0.58^{b}$ & $8.00 \pm 0.58^{c}$ & $13.33 \pm 0.33^{e}$ & NI & N.A & $\begin{array}{c}12.00 \\
\pm 0.00^{\mathrm{d}}\end{array}$ \\
\hline C. A ATCC10231 & $4.00 \pm 0.58^{a}$ & $7.33 \pm 0.33^{b}$ & $10.00 \pm 0.58^{c}$ & $14.33 \pm 0.33^{d}$ & NI & N.A & $\begin{array}{c}14.67 \\
\pm 0.33^{\mathrm{d}}\end{array}$ \\
\hline C. $G$ & NI & $\mathrm{NI}$ & $6.33 \pm 0.33^{\mathrm{a}}$ & $10.00 \pm 0.58^{b}$ & NI & N.A & $\begin{array}{c}16.33 \\
\pm 0.00^{c}\end{array}$ \\
\hline
\end{tabular}

Legend; Values are Mean \pm S.E.M (mm), Values followed by different alphabet along the rows are significantly different at $\mathrm{p} \leq 0.05$, NI= no inhibition, N.A= not applicable, $\mathrm{Chl}=$ Chloramphenicol, Myz=Miconazole, B.S=Bacillus subtilis, $\mathrm{S} . \mathrm{A}=$ Staphylococcus aureus, E.C= Escherichia coli, K. $P=$ Klebsiella pneumoniae, Ps.A= Pseudomonas aeruginosa, A.F=Aspergillus flavus, C.A= Candida albicans, C.G= Candida glabrata 
Table 2 Antimicrobial activity of essential oil of $K$. senegalensis stem bark on selected pathogens

\begin{tabular}{|c|c|c|c|c|c|c|}
\hline \multirow{2}{*}{$\begin{array}{l}\text { Conc. }(\mu \mathrm{g} / \mathrm{ml}) / \\
\text { Organisms }\end{array}$} & \multicolumn{6}{|c|}{ Zones of inhibition (mm) } \\
\hline & 6.3 & 12.5 & 25 & 50 & DMSO(30\%) & Chl \\
\hline B. $S$ & $\mathrm{NI}$ & $4.33 \pm 0.33^{a}$ & $6.33 \pm 0.33^{b}$ & $9.67 \pm 0.67 c$ & NI & $11.00 \pm 0.00^{\mathrm{d}}$ \\
\hline B. S ATCC6633 & NI & $5.67 \pm 0.67 a$ & $6.33 \pm 0.33^{a}$ & $10.00 \pm 0.58^{b}$ & NI & $13.33 \pm 0.33^{c}$ \\
\hline S. $A$ & $3.33 \pm 0.33^{a}$ & $5.33 \pm 0.33^{b}$ & $7.67 \pm 0.67 \mathrm{c}$ & $11.67 \pm 0.33^{\mathrm{d}}$ & NI & $13.00 \pm 0.00^{\mathrm{e}}$ \\
\hline S. A ATCC25923 & $4.67 \pm 0.67^{a}$ & $6.67 \pm 0.33^{b}$ & $7.67 \pm 0.33^{b}$ & $11.33 \pm 0.33^{c}$ & NI & $14.67 \pm 0.33^{d}$ \\
\hline E. $C$ & $6.33 \pm 0.33^{a}$ & $10.33 \pm 0.33^{b}$ & $13.33 \pm 0.33^{c}$ & $16.33 \pm 0.33^{e}$ & NI & $14.00 \pm 0.00^{\mathrm{d}}$ \\
\hline E. C ATCC25922 & $7.33 \pm 0.33^{a}$ & $10.00 \pm 0.58^{\mathrm{b}}$ & $12.67 \pm 0.33^{c}$ & $16.33 \pm 0.33^{\mathrm{d}}$ & NI & $15.67 \pm 0.33^{d}$ \\
\hline K. $P$ & $\mathrm{NI}$ & NI & $7.00 \pm 0.58^{a}$ & $11.00 \pm 1.15^{b}$ & NI & $12.33 \pm 0.00^{b}$ \\
\hline PS. $A$ & $\mathrm{NI}$ & NI & $4.67 \pm 0.67^{a}$ & $7.67 \pm 0.33^{b}$ & NI & $13.33 \pm 0.33^{c}$ \\
\hline
\end{tabular}

Legend: Values are Mean \pm S.E.M (mm), Values followed by different alphabet along the rows are significantly different at $\mathrm{p} \leq 0.05$, NI= no inhibition, N.A= not applicable, Chl=Chloramphenicol, Myz=Miconazole, B.S= Bacillus subtilis, $\mathrm{S} . \mathrm{A}=$ Staphylococcus aureus, E.C= Escherichia coli, K. $P=$ Klebsiella pneumoniae, Ps.A= Pseudomonas aeruginosa

The values obtained for the MIC determination ranged from $5-40 \mu \mathrm{g} / \mathrm{ml}$ and 6.3 to $20 \mu \mathrm{g} / \mathrm{ml}$ for the leaf and stem bark oils respectively (Table 3). The leaf oil was more active on S. aureus ATCC25933, S. pyogenes, P. aeruginosa, A. flavus, $C$. albicans while the stem bark oil showed more activity on B. subtilis, B. subtilis ATTCC6653, S. aureus, E. coli and E. coli ATCC25922 with MIC values ranging from 5 to $10 \mathrm{ug} / \mathrm{ml}$. The inhibitory effect obtained on these microorganisms is significant for the plant materials as the previous epidemiological study by [22] on these microorganisms indicated that they are highly resistant to ampicillin, chloramphenicol and augmentin. The values obtained in the present study were in agreement with those reported by $[23,24]$ who assessed the antimicrobial potential of the essential oils obtained from some members of the family Meliaceae. The results revealed that $K$. senegalensis may be a good source of antimicrobial agent with interesting activity on multi resistant strains and may therefore be exploited for the development of new therapeutic agents.

Table 3 MIC of the essential oils of $K$. senegalensis leaf and stem bark against selected pathogens $(\mu \mathrm{g} / \mathrm{ml})$

\begin{tabular}{lll}
\hline Microorganisms & Leaf & Stem bark \\
\hline Bacillus subtilis & 40 & 10 \\
B. subtilis & 20 & 10 \\
Escherichia coli & 15 & 5.0 \\
E. coli ATCC25922 & 15 & 5.0 \\
Enterococcus faecalis & ND & ND \\
Staphylococcus aureus & 6.3 & 6.0 \\
S. aureus ATCC25923 & 5.0 & 5.0 \\
Streptococcus pyogenes & ND & ND \\
S. epidermidis & ND & ND \\
S. typhi & ND & ND \\
S. typhi ATCC6539 & ND & ND \\
Klebsiella pneumoniae & ND & 20 \\
Pseudomonas aeruginosa & 10 & ND \\
Aspergillus flavus & 10 & ND \\
Candida albicans & 5.0 & ND \\
C. albicans ATCC10231 & 5.0 & ND \\
Trichophyton rubrum & ND & ND \\
\hline & Legend: ND= Not detected & \\
& &
\end{tabular}

Legend: $\mathrm{ND}=$ Not detected 
The results obtained on the scavenging effect of the plant oils on 2, 2-diphenyl-1-picrylhydrazyl radical (DPPH) are presented in Figure 1. The inhibition percentage of the different concentrations of the tested oils increased with increased in oil concentration. At the highest concentration of $2 \mathrm{mg} / \mathrm{ml}$, the percentages of inhibition were $79.64 \pm 0.29 \%$ and $83.73 \pm 0.02 \%$ as compared with the reference ascorbic acid (93.81 $\pm 0.05 \%$ and $86.26 \pm 0.02 \%)$ for the leaf and stem bark oils respectively. This observation agrees with the work of $[25,26]$ on antioxidant properties of some plant oils. The Ic $\mathrm{c}_{50}$ values for the leaf and stem bark oils were $1.40 \pm 0.29$ and $1.00 \pm 0.02$ respectively. The leaf oil exhibited better antioxidant activity and broader antimicrobial activity against the test pathogens. The identified fractions exhibited significant antioxidant activity when compared with ascorbic acid standard $(0.40 \pm 0.15)$. These results however differ from the work of [27] who obtained a higher concentration with K. senegalensis but agree with [28] who obtained closer results from the same plant. The study indicated that the plant oils have good antioxidant potential comparable to the ascorbic acid used as positive control and could therefore have application in cosmetic and pharmaceutical industry.

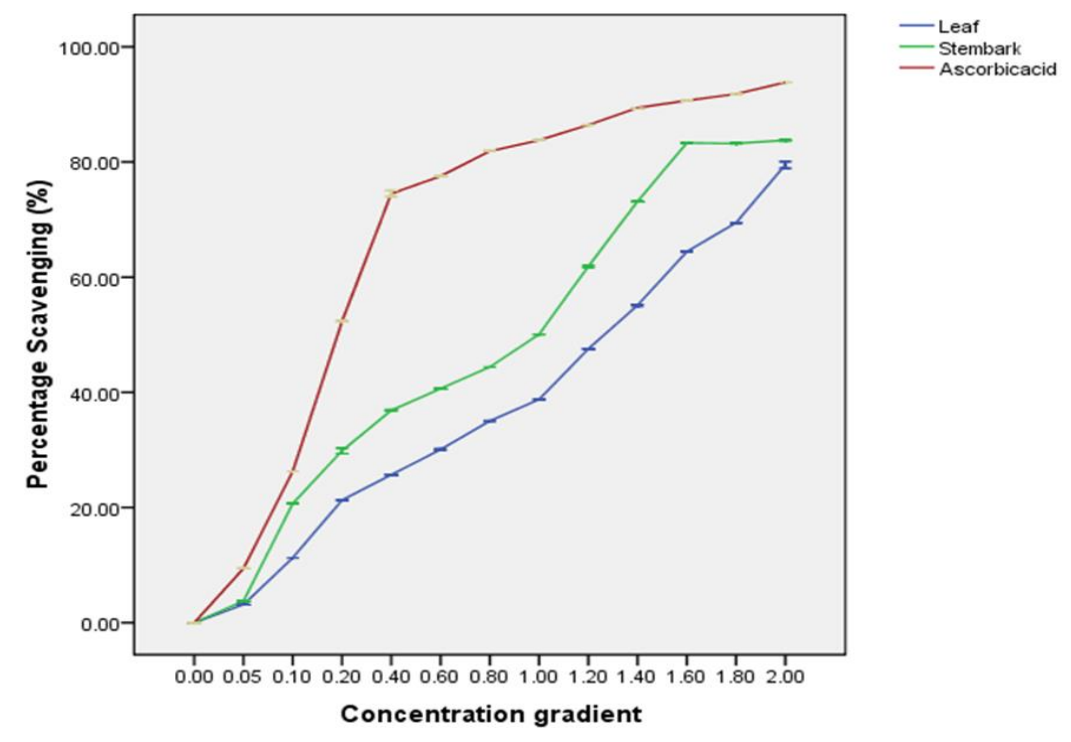

Figure 1 Antioxidant activity of essential oils from K. senegalensis (\%DPPH scavenging inhibition)

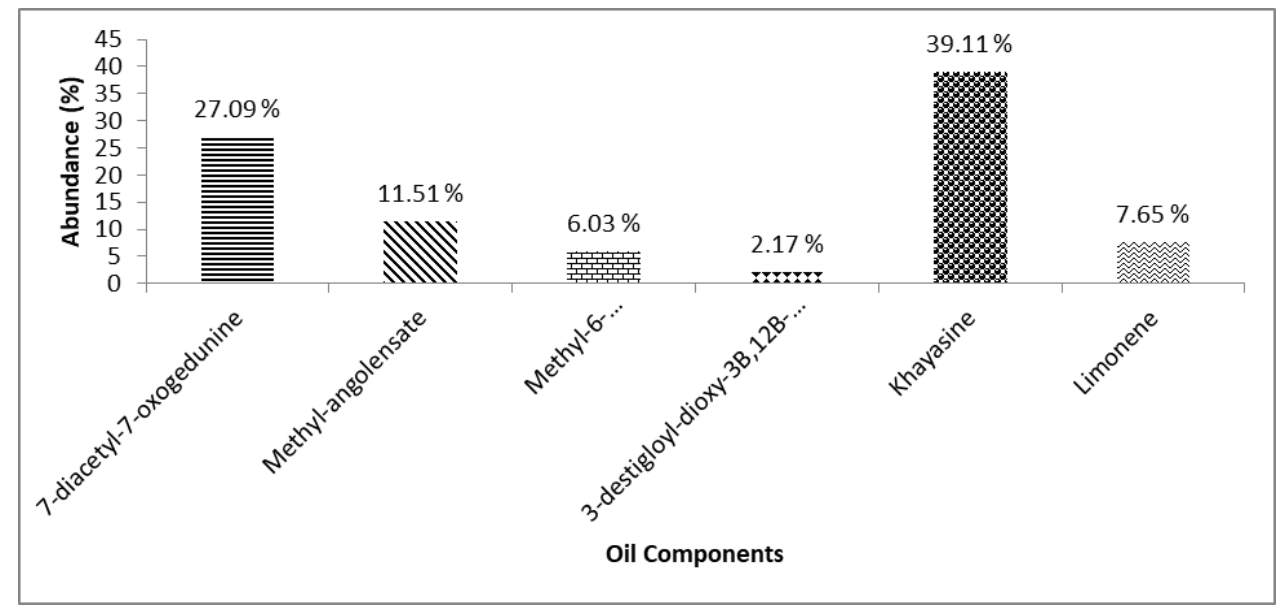

Figure 2 Chemical composition of Khaya senegalensis leaf oil

The chemical composition of the plant materials as presented in Figures 2 and 3 revealed that the plant materials contained a complex mixture of compounds. The leaf oil was mostly khayasin (39.11\%), followed by 7-diacetyl-7oxoguanine $(27.09 \%)$ while 3-destigloyl-dioxy3B-12B diacetoxyswietenine constituted the least (2.17\%). The stem bark oil compounds were mostly ivorenolide (28.27\%), followed by khivorine (16.33\%) and lowest amount of limonene (6.59\%). Secondary metabolites such as alkaloids, terpenoids, saponins, tannins, phenolic and flavonoids 
from $K$. senegalensis have also been implicated in antimicrobial activity against selected pathogens [29, 30, and 31]. Several earlier studies have suggested that the stem bark of $K$. senegalensis mainly contain limonoids [32]. However, the present discovery of 3-diaacetyl khivorine and khivorine in the stem bark oil agreed with the works of [33] who isolated the same compounds from the seed while some of the compounds had been reported to possess antimicrobial, antioxidant and anticancer activity [34,35, 36,37] which supports the present investigation.

However, it is significant to note that all the compounds isolated in this study were different from the eight compounds isolated from the bark of K. senegalensis by [38]. The variation of the compounds present in the essential oils can be attributed to different factors such as seasonality, circadian rhythm, age, temperature, water availability, ultra violet radiation, nutrient content, atmospheric pollution and attack by pathogens [39]. The presence of these compounds may be attributed to the strong antimicrobial activity of the oils and its wide spread folkloric use in treatment of diseases caused by some of the test pathogens.

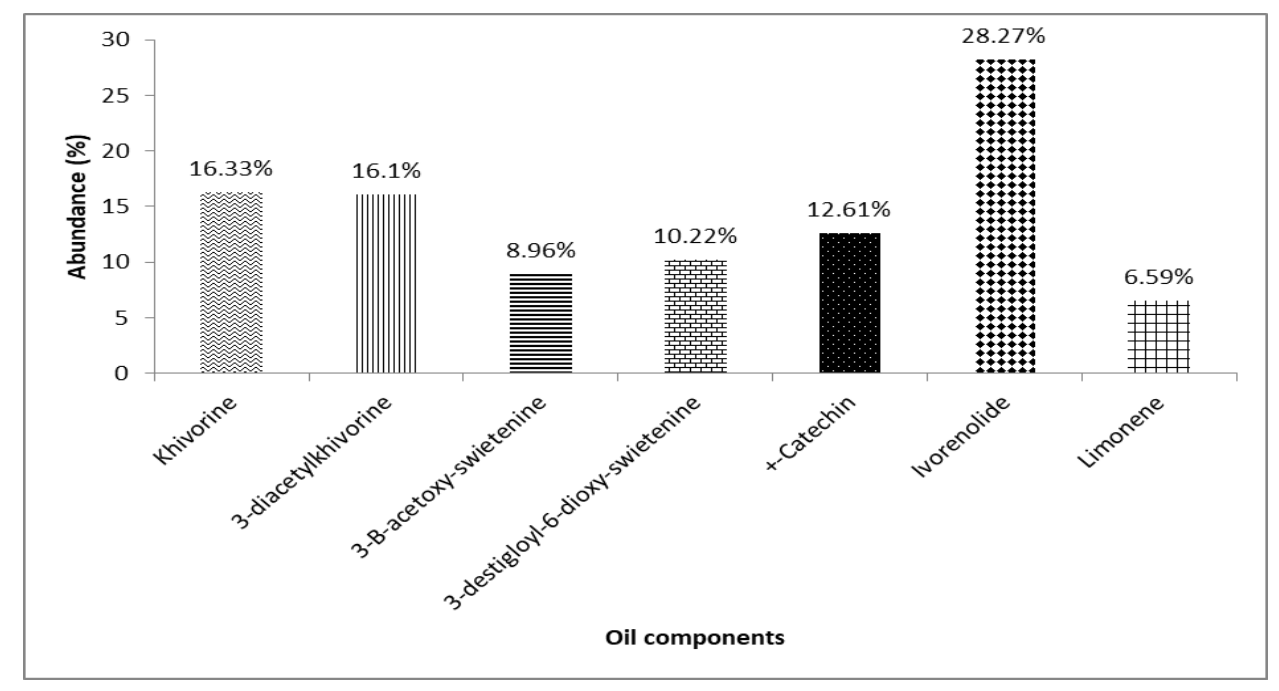

Figure 3 Chemical composition of Khaya senegalensis stems bark oil

\section{Conclusion}

The demonstration of broad antimicrobial spectrum, high free radical scavenging activity and the presence of bioactive compounds in the plant materials could explain the basis for the use of $K$. senegalensis in the traditional treatment of diseases caused by the test microorganisms. However, efforts should be geared toward the isolation of active ingredients in the identified compounds in order to establish the possible use of the essential oils as sources of alternative antibiotics.

\section{Compliance with ethical standards}

\section{Acknowledgments}

The authors are grateful to the Management of Rufus Giwa Polytechnic, Owo and TetFund, Nigeria for providing the platform and funds for the successful completion of this research work.

\section{Disclosure of conflict of interest}

The authors declare no conflict of interest in any form.

\section{References}

[1] James BJ, Wardle J, Steel A and Adams J. (2018) Traditional, complementary and alternative medicine used in sub-Sahara Africa: a systematic review. BMJ Glob Health.

[2] Manandhar S, Luitel S and Dahal RK. (2019). In vitro antimicrobial activity of some medicinal plants against human pathogenic bacteria. Journal of Tropical Medicine. 
[3] Rashed K, Chang C, Wu LY and Peng WH. (2013). Hepatoprotective effect from Cedrela odorata and phytochemical profile. Journal of Pharmaceutical Cosmetic Science, 1(5), 45-52.

[4] Munira B, Gururaja GM, Deepak M, Roopashree TSS and Shashidhara S. (2013). An overview on phytochemistry and pharmacological properties of Gmelina arborea. Journal of Natural Product and Plant Research, 3(4), 79-88.

[5] Pallav KD, Ragini G and Anupam KP. (2014). Analysis and evaluation of antimalarial activity of Azadiracchta indica. The Pharma Innovation Journal, 3(9), 12-16.

[6] Zhaparkulova K, Srivedavyasasri R, Sakipova Z and Ross SA. (2015). Phytochemical and biological studies on Ziziphora bungeana. Planta Medcine, 81-87.

[7] Keay RWJ, Onochie CFA and Stanfield DP. (1989).Nigerian Tree. Nigerian National press limited, Apapa, Lagos, Nigeria, 1-14.

[8] Gill LS. (1992). Ethnomedical uses of plants in Nigeria. University of Benin Press.

[9] Onifade AK, Fatope MO, Deadman ML and AI-Kindy SMZ. (2008). Nematicidal activity of Haplophylum tuberculatum and Plectranthus cylindraceus oils against Meloidogyne Javanica. Biochemical Systematics and Ecology, 36, 679-683.

[10] Adeshina GO, Kunle OF, Onaolapo JA, Ehinmidu JO and Odama LE. (2011). Evaluation of antimicrobial potentials of methanolic extract of Alchornea cordifolia leaf. European Journal of Scientific Research, 49(3), 433-441.

[11] Oyeleke SB, Dauda BEN and Boye OA. (2008).Antimicrobial activity of Fiscus capensis. African Journal of Biotechnology, 7(10), 1414-1417.

[12] Perez C, Pauli M and Bazerque P. (1990). An antibiotic assay by the agar-well diffusion method. Actabiologiaeet Medicine Experimentalis, 15, 113-115.

[13] Ghosh G, Subudhi BB, Badajena LD, Ray J, Mishra MK and Mishra SK. (2011). Antibacterial activity of Polyalthia longifolia var. Angustifolia stem bark extract. International Journal of Pharmaceutical Technology and Research, 3(1), 256-260.

[14] Ngbolua KN, Fatiany PR, Robijaona B, Randrianirina, AYO, Rajaonariveto PJ, Rasondratoro B, Raharisolalao A, Moulis C, Mudogo V and Mpiana D. (2014). Ethnobotanical survey, chemical composition and in vitro antimicrobial activity of essential oils from the root bark of Hazomakinia voyroni (Jum.) Capuron (Hernandiaceae). Journal of Advancement in Medical and Life Sciences, 1(1), 1-6.

[15] Adams RP. (2012). Identification of essential oil components by Gas Chromatography/Mass Spectrometry: 4th ed. Allured Business Media, Illinois, 100-503.

[16] Hussain AI, Anwar F, Chatha SAS, Jabbar A, Mahboob S and Nigam OS. (2010). Rosmarinus officinalis essential oil: Antiproliferative, antioxidant and antibacterial activities. Brazilian Journal of Microbiology, 41, 1070-1078.

[17] Solomon EP, Berg LR and Martin DW. (2005). Biology. 7th edition, Thomson Learning, Inc-Brooks/Cole, Belmont, USA.

[18] Bla KB, Trebissou JND, Bidie P, Assi, YJ, Zirihi-Guede N and Djaman AJ. (2015). Etude ethnopharmaclogique des plantes antipaludiques utilises chez les Baoule-N'gbande Toumodi dan le centre de la Cote d'Ivoire. Applied Biological Sciences, 85, 7775-7783.

[19] Koffi AJ, Bla K B, Yapi HF, Bidie AP and Djaman AJ. (2015).Phytochemical screening of some medicinal plants in cote D'ivoire and evaluation of their extraction efficiency. International Journal of Pharmacognosy and Phytochemical Research, 7(3), 1-11.

[20] Opawale B, Oyetayo M and Adaramola -Ajibola M. (2018). Antimicrobial and Phytochemical Screening of Stem bark extracts of Lovoa trichiliodes ( Harm) and Trichilia heudelotii Planc (Harm), GSC Biological and Pharmaceutical Sciences, 2(1), 1-8.

[21] Olasupo AD, Aborisade AB and Olagoke OV. (2018). Phytochemical analysis and antibacterial activities of spinach leaf. Journal of Phytomedicine and Clinical Therapeutics, 6(28).

[22] Assob NJC, Weledgi EP, Njunda AL, Bolimo F, Asongalem EA, Kanga FHL, Achidi EA, Penlap BV and Ndumbe PM. (2009). Bacteriological and mycological characterization of some Buea subdivisions (South West Region of Cameroon). Health Science and Discovery, 10, 10-16. 
[23] Sairam M, Ilavazhagan G, Sharma SK, Dhanraj SA, Suresh B, Parida M.M, Jana AM, Devendra K and Selvamurthy W. (2000). Antimicrobial activity of a new vagina contraceptive NIM-76 from neem oil (Azadirachter indica). Journal of Ethnopharmacology, 71(3), 377-382.

[24] Opawale BO, Onifade, AK and Ogundare AO. (2016). Antimicrobial, Free radical scavenging and cytotoxic activities of Khaya grandifoliola C.Dc. Malaysian Journal of Microbiology, 12(3), 233-239.

[25] kanat SR, Arjun K and Sharma A. (2011). Antioxidant and antimicrobial activity of legume hulls. Food Research International, 44, 3182-3187.

[26] Abere TA, Okolo PE and Agoreyo FO. (2010). Antidiarrhoea and toxicological evaluation of the leaf extract of Dissotis rotundifolia and Triana melastomatacea. BMC Complement Alternative Medicine, 10, 71.

[27] Laleye OAF, Ahissou H, Olounlade AP, Azando VBE, Dansou C and Laleye A. (2015). Phytochemical, screening and evaluation of antihyperglycemic, antiradical and acute oral toxicity activities of aqueous extracts of stem bark of Khaya senegalensis A. Juss (Meliaeceae) from Benin. International Journal of Pharmacognosy and Phytochemical Research, 7(3), 1-11.

[28] Ibrahim MAN, Koorbanally MD and Shahidi I. (2014). Antioxidative activity and Inhibitory of key enzymes linked to type-2 diabetes (a-glucosidase and a-amylase) by Khaya senegalensis. Acta Pharmaceutical, 64, 311-324.

[29] Stephanie DP, Guy K, Alvaro V and Sandy VV. (2013). The In vitro antimicrobial of Larandula angustifolia essential oil in combination with other aroma-Therapeutic oils. Evidence Based Complementary and Alternative Medicine 2013, 1-5.

[30] Scur MC, Pinto FGS, Pandini JA, Costa, WF, Leite CW and Temponi LG. (2016). Antimicrobial and antioxidant activity of essential oil and different plant extracts of Psidium cattleianum Sabine. Brazillian Journal of Biology, 72(1), 101-108.

[31] Rabadeaux C, Vallette L, Sirdaarta J, Craig D and Cock IE. (2017). An examination of the antimicrobial and anticancer properties of Khaya senegalensis (Desr.) A.Juss bark extracts. Pharmacognosy Journal, 9(4), 504-518.

[32] Yuan T, Yang C and Zhang C. (2009). Two limonoids, khayalenosids A and B with an unprecedented B-oxa-tricyclo (4.3.2.02.7) undercane motif from Khaya senegalensis. Organic letters, 11, 612-620.

[33] Hussain H, Ahmed AH, Ahmed AR and Javid H. (2013). Chemistry and biology of essential oils of Genus Boswellia. Evidence-Based Complementary and Alternative Medicine, ID 140509, 1-12.

[34] Traore L, Boua BB, Guessennnd NK, Kadja BA, Mamyrbekova-Bekro JA and Bekro, YA. (2015). In vitro antibacterial potential of glycosidic and aglyconic crude extracs of Cassia sieberiana DC (Cesalpiniaceae) and Khaya grandifoliola C.Dc. (Meliaceae): A comparative survey. International Journal of Pharmaceutical Sciences and Research, 6 (7), 2728-2733.

[35] Pandini JA, Pinto, FGS, Scur, MC, Santana CB, Costa WF and Temponi LG. (2017). Chemical composition, antimicrobial and antioxidant potential of the essential oil of Guarea kunthiana A. Juss. Brazillian Journal of Biology, 78 (1).

[36] Mordi RA, Olasehinde GI, Okedere, AP, Elegwule. AN, Ayo-Ajayi JI, Jonathan OH, Onibokun AE, Adesola AA and Uchenna DO. (2019). Antibacterial activity of moderately volatile components of the oil extracted from the seeds of Dacrodes edulis G. LAM. Asian Journal of Pharmaceutical and Clinical Research, 12 (3), 246-249.

[37] Omototinbo BI, Afe AE and Kolapo 00. (2018). Bioactive constituents of essential oil from Khaya senegalensis bark extracts. American Journal of Chemical and Engineering, 2(2), 50-54.

[38] Gobbon-Neto L and Lopes NP. (2007). Plants medicinais: fotores de influencia no conteudo de metabolites secundarios. Quimica Nova, 30(2), 374-381.

\section{How to cite this article}

Opawale BO and Adaramola-Ajibola MK. (2019). Chemical composition, antimicrobial and free- radical scavenging activity of essential oils from Khaya senegalensis (Desr) A. Juss. GSC Biological and Pharmaceutical Sciences, 9(3), 2634. 